\title{
A PROPOSED CENTRALISED DISTRIBUTION MODEL FOR THE SOUTH AFRICAN AUTOMOTIVE COMPONENT INDUSTRY
}

\author{
Micheline J Naude, University of KwaZulu-Natal
}

\begin{abstract}
Purpose: This article explores the possibility of developing a distribution model, similar to the model developed and implemented by the South African pharmaceutical industry, which could be implemented by automotive component manufacturers for supply to independent retailers.

Problem Investigated: The South African automotive components distribution chain is extensive with a number of players of varying sizes, from the larger spares distribution groups to a number of independent retailers. Distributing to the smaller independent retailers is costly for the automotive component manufacturers.
\end{abstract}

Methodology: This study is based on a preliminary study of an explorative nature. Interviews were conducted with a senior staff member from a leading automotive component manufacturer in KwaZulu Natal and nine participants at a senior management level at five of their main customers (aftermarket retailers).

Findings: The findings from the empirical study suggest that the aftermarket component industry is mature with the role players well established. The distribution chain to the independent retailer is expensive in terms of transaction and distribution costs for the automotive component manufacturer. A proposed centralised distribution model for supply to independent retailers has been developed which should reduce distribution costs for the automotive component manufacturer in terms of (1) the lowest possible freight rate; (2) timely and controlled delivery; and (3) reduced congestion at the customer's receiving dock.

Originality: This research is original in that it explores the possibility of implementing a centralised distribution model for independent retailers in the automotive component industry. Furthermore, there is a dearth of published research on the South African automotive component industry particularly addressing distribution issues.

Conclusion: The distribution model as suggested is a practical one and should deliver added value to automotive component manufacturers in that it could reduce distribution costs and also may improve customer service.

Key Words: Automotive Component Manufacturers; Value Chain; Customer Value; Costs; Distribution Strategies; Distribution Channel; E-Commerce; Centralised Distribution Model.

\section{INTRODUCTION}

Businesses must be competitive in order to sell their goods or services in the marketplace. Competitiveness determines whether a firm prospers, survives, or fails. Competitiveness can be defined as how effectively a business meets the wants and needs of customers relative to other businesses that offer similar products or services (Stevenson, 2005:36). Firms must continuously strive to improve their competitiveness due to the continuous increase in competition in the global and local markets. As a direct result thereof, the philosophy of continuous improvement was developed in order to sustain a competitive advantage.

The automotive component distribution industry is experiencing many challenges due to numerous pressures. These pressures include among others: saturation of demand and intense competition; reducing profit margins and increasing fixed costs; and developments in information and communication technologies (Buzzavo 2008:105).

A characteristic of the automotive retail aftermarket distribution chain is that the manufacturer is not in the business of distribution, but manufactures automotive components. The distribution network in South Africa is broad, with independent retailers geographically dispersed. Prices are dependent on the delivery volumes. In other words, the greater the bulk quantities, the lower the selling price charged by the automotive component manufacturer. As it is the automotive component 
manufacturer who pays for the freight or carriage costs, the freight cost in relation to the invoice value of stock is significant. This is the reason for the proposed distribution model, to encourage larger shipments.

In this article the state of the literature with regard to the following aspects will be reviewed: categories of businesses, competitive advantage and customer value, Porter's value chain and the distribution strategies of the South African pharmaceutical and automotive component industry. The research methodology stipulating the research undertaken, the findings, analysis and interpretation of the findings, the proposed centralised distribution model and a conclusion will then be dealt with.

\section{THEORETICAL BACKGROUND}

This section deals with the theoretical background of the study. To set the scene, the various categories of businesses within the automotive industry can be dealt with as follows:

\section{Categories of businesses}

The global automotive industry consists of four distinct categories, namely:

1. original equipment manufacturers (OEM) or automotive assemblers. This category comprises manufacturers of passenger and commercial vehicles.

2. original equipment suppliers (OES). This category comprises both automotive parts and accessory sales through the original equipment manufacturers.

3. automotive component manufacturers (ACMs). Automotive component manufacturers supply components to original equipment manufacturers, original equipment suppliers and the independent aftermarket and retailers.

4. $\quad$ automotive retail aftermarket, which comprises of automotive parts and accessory sales, the larger retail groups, the independent retailers and repair shops.

(adapted from Barnes \& Morris, 2008:34)

The focus of this article is on automotive component manufacturers' supplying components to independent retailers, as part of the automotive retail aftermarket.

\section{Competitive Advantage and Customer Value}

The building blocks of competitive advantage are value activities. Hill and Jones (2004:79-87) state that competitive advantage is the ability of one firm to outperform other firms because it produces desired goods or services more efficiently and effectively than its competitors. The four building blocks of competitive advantage are superior efficiency, quality, innovation and responsiveness to customers. Although the major purpose of competitive advantage is to serve customers' real needs and to purely outperform competitors, the goal is obviously to be more competitively effective than one's competitors (Jones \& George, 2003:79-87; Kotler, 2000:82). Therefore, a business is said to have a competitive advantage over its competitors when it increases or keeps its market share and achieves a greater profitability than the average profitability for all companies in its industry (Hill \& Jones, 2004:4). Supply chain management creates a competitive advantage by linking the resources, technical skills and management acumen of all participants (on all levels or tiers) in such a manner that the organisation differentiates itself from its competition in the eyes of the customer while at the same time lowering the cost of satisfying customer demand across the whole chain (Hugo, Badenhorst-Weiss and van Biljon, 2004:6).

\section{Porter's Value Chain}

Michael Porter's value chain analysis disaggregates a business into nine value-creating and strategic activities and either primary or support activities (Grant, Lambert, Stock and Ellram, 2006:14) (see figure 1). 
Figure 1: Porter's Value Chain

Primary Activities and Costs

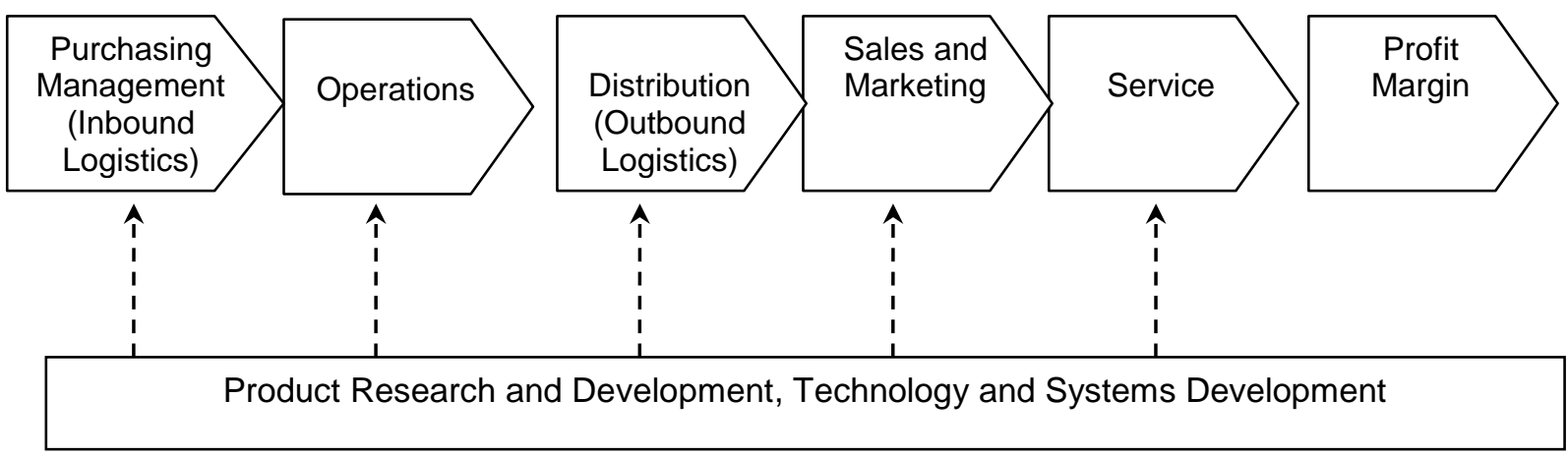

Human Resources Management

General Administration

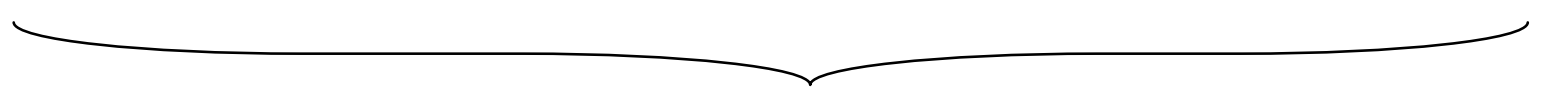

Support Activities and Costs

Source: Adapted from Thompson, Gamble and Strickland, 2006:96

Primary activities include the activities in a business of those involved in the physical creation of the product, marketing and transfer to the buyer and after-sale support. The goal of primary activities is to increase profit margins by creating value that exceeds the cost of these activities. Support activities in a business are seen as non-value creating. However, the goal of these activities is to assist the business as a whole, by providing inputs that allow the primary activities that create competitive advantage to take place on an ongoing basis (Pearce \& Robinson, 2007:159; Grant et al, 2006:14).

Inbound and outbound logistics comprise two of the primary activities. Grant et al (2006:17) identified the key logistics activities required to facilitate the flow of product from point of origin to point of consumption. These are: customer service and support; demand forecasting/planning; purchasing and procurement; inventory management; logistics communication and order processing; material handling and packing; transportation; facilities site selection; warehousing and storage; return goods handling and reverse logistics. These aspects were considered in the formulation of the proposed centralised distribution model for the automotive component industry.

The next section deals briefly with distribution strategies, centralised versus decentralised systems and the impact of the Internet on supply chain strategies.

\section{Distribution Strategies}

Simchi-Levi, Kaminsky and Simchi-Levi (2008:13) observe that (1) the selection of a set of warehouse locations and capacities; (2) determining production levels for each component at each plant; and (3) setting transportation flows either from plant to warehouse or warehouse to retailer; need to be determined in such a manner as to minimise total production costs, inventory levels and transportation costs, whilst at the same time satisfying customer requirements. The authors state that this is a complex optimisation problem. Stevenson (2009:31) concurs as distribution decisions 
are strongly influenced by transportation costs and deliveries as these costs often represent a significant portion of total cost. A distribution decision focuses on what customers want, when they want it and how much is needed. Therefore, in order to find a solution to the optimisation problem, advanced technology and approaches are vital (Hugo et al 2004:176).

Many businesses are faced with the challenge of whether they should centralise or decentralise their distribution centre. Each strategy impacts on inventory levels, transportation costs and service levels. These factors are significant not only for a single business determining its distribution strategy, but also for competing retailers who need to determine how much they can collaborate with each other (Simchi-Levi et al 2008:14; Mangan, Lalwani and Butcher, 2008:139). In addition, it is imperative that businesses identify the hidden challenges surrounding the distribution and sale of goods and services and overcome these before considerable funds are invested (Jones \& George, 2003:193).

Simchi-Levi et al (2008:230-232) acknowledge that an effective supply chain requires the integration of the front end (customer demand) and the back end (the production and manufacturing processes) of the supply chain. Fundamentally there are two possible distribution strategies, namely a direct shipment distribution strategy (which exists to bypass warehouses and distribution centres) and intermediate inventory storage point strategies (traditional warehousing strategy and cross-docking). One of the decisions in a traditional warehouse system is whether to use a centralised or decentralised system.

\section{Centralised versus decentralised system}

In a centralised system, decisions are made at a central location for the whole supply network. The objective under this type of system is to minimise total costs of the system while satisfying customer requirements. A centralised system may include many different businesses. In a decentralised system, each facility identifies its most effective strategy without considering the impact on the other facilities in the supply chain (Simchi-Levi et al 2008:231; Hugo et al 2004:284). As indicated in Jonsson (2008:232), for a number of years developments have been towards an increasing degree of centralisation.

According to Bowersox, Closs and Cooper (2002:383), in a centralised system the warehouse receives parts from a number of suppliers which can be combined into a large shipment to a specific customer. The benefits are: (1) the lowest possible freight rate; (2) timely and controlled delivery; (3) reduced congestion at the customer's receiving dock; and (4) reduced costs.

The focus of this study is on the formulation of a proposed centralised distribution model for the automotive component industry. In the case of the proposed model, the distribution centre will receive components from a number of automotive component manufacturers which can be combined into a large shipment to a specific independent retailer.

\section{The impact of the Internet on supply chain strategies}

The impact of the Internet and e-commerce on the economy in general, and business practice in particular, has been vast. Many companies acknowledge that e-business and e-commerce provide convenience and cost reduction (Simchi et al, 2008:198). E-commerce typically means making the selling processes of an organisation available over the Internet. The selling processes may include key business processes such as customer relationship management, supply-chain management, and enterprise resource planning integration. Putting these processes on the web means that customers can do more than place an order and pay for it. They can track the status of an order from placement to delivery, receive prompt support once it has arrived, and easily place related orders. For the organisation, having these processes available online makes the web more than just another sales channel. It can help optimise inventory by directly interfacing with suppliers, improve collections by tracking customers' payment history, and build brand loyalty by providing 
customers with the quickest, most efficient, most reliable buying experience (Laudon \& Laudon, 2004:24; Bowersox, Closs \& Cooper, 2007:87).

A key challenge facing the automotive industry is the integration of supply management with information and technology management. Original equipment manufacturers and their suppliers have to share more information to help maintain market share. Therefore it is important to integrate supply chain management with information technology. An example is the development of Covisint. Covisint globally is recognised as the most comprehensive online communication system. Initially it was developed as a supply chain management solution for the automotive industry, but it has expanded in scope and now serves many other purposes for a variety of industries (Manufacturing, 2009). Covisint is the B2B automotive e-market place supported by the main original equipment manufacturers and originally Covisint instigated reverse auctions for the "Big 3" automotive equipment manufacturers, namely Ford Motor Company, General Motors and Daimler-Chrysler (Benton, 2007:52; Applegate \& Collins, 2005:1).

This concludes the section on distribution strategies. The next section deals with an overview of the pharmaceutical distribution chain, as the pharmaceutical industry in South Africa successfully developed a unique distribution model. This model was examined to determine whether a similar one could be developed for the South African automotive component industry for supply to independent retailers.

\section{Overview of the Pharmaceutical Distribution Chain}

A number of years ago the pharmaceutical industry found itself in a well-traded market. All of the international players were in South Africa manufacturing and retailing the international drug and medicine brands. The pharmaceutical companies had worked for a number of years on the basis that they would import / manufacture their own established brands, but most were not in the business of distributing these products. There were various wholesalers who were prepared to handle the function of distributing to the retailers, particularly the pharmacies. It suited many of the drug companies to have such organisations distribute their products to the numerous pharmacies across the country (Competition Tribunal, 2000:02), and those who did not, had their own regional warehouses and fleets of vehicles to deliver their products. The distribution logistics were difficult as not only were the pharmacies widely distributed but each pharmacy required small quantities of each brand / product. Thus the delivery costs were often very high in relation to the size and value of each delivery.

Over the years, the drug companies found that their delivery costs were growing and the wholesalers were getting more aggressive and demanding more margin. A solution was needed to consolidate and streamline the network of distribution. The pharmaceutical organisations met and came up with a solution to address their existing distribution problems. As confirmed in Andel (2008:7) the "buy and hold" wholesale model was no longer viable.

Between them they developed and implemented a unique distribution model that is supported by an information technology platform, to ensure the integrity of the products it handles while lowering costs and increasing profitability for pharmaceutical manufacturers (UTi Acquires Leading Pharmaceutical Distributor IHD, 2004). International Healthcare Distributors (Pty) Ltd (IHD) was launched in December 1993 and today is a leading pharmaceutical distributor in South Africa serving end dispensers, namely pharmacists, doctors and clinics. Ownership of IHD is held by a consortium led by UTi Worldwide (About IHD, 2008).

IHD offers pharmaceutical manufacturers cost-effective logistical and warehousing support and a range of distribution services for which clients are charged a fee. IHD has five distribution centres (leased warehouses) located around South Africa and each features climate controlled state of the art facilities to assure proper storage and handling of client inventory (UTi Acquires Leading Pharmaceutical Distributor IHD, 2004). 
To handle the logistics of moving drugs around the company, an efficient computer system is used. The "web enabling" of this system through a switch / hub has been developed by the logistics company. The reasons for the success of IHD are in the expertise and services offered to their clients. Prior to IHD, pharmaceutical manufacturers were only able to obtain limited market data. IHD provides secure daily data downloads detailing for example to whom a product was sold, where the customer is located and at what price the product was sold. It is noted that the ability to track a specific customer and invoice in the pharmaceutical industry is critical in the event of product recalls, for example (About IHD, 2008).

This concludes the theoretical background. The next section deals with the purpose and methodology.

\section{PURPOSE}

The purpose of this article is to investigate the possibility of developing a distribution model, similar to the one developed and implemented by the South African pharmaceutical industry, which could be implemented by automotive component manufacturers for supply to independent retailers. Supply to the major distribution groups has been excluded from this study as supply by the automotive component manufacturers to such groups is well controlled, generally efficient and cost effective for both supplier and customer. Further, supply is often centralised to these retailers via a central distribution warehouse. (Autozone, 2009; Parts incorporated Africa, 2009).

The scope of this article is limited to the sell and distribution side of the value chain, and does not include the full extent of an integrated business solution, encompassing all aspects of the organisation. The sell side includes the selling activities to the retail and distribution side as well as the service / support activities such as outbound logistics, marketing and sales functions, and customer service activities.

\section{Methodology}

As the title indicates, "a proposed centralised distribution model for the South African automotive component industry", this study is a preliminary study and a limited number of participants were included in the study.

This study is by nature both descriptive and exploratory and contains qualitative and empirical aspects. There are two reasons for this approach, namely:

1. important aspects of the study are based on existing research and literature; and 2. primary sources had to be explored to determine current distribution strategies within the automotive component manufacturers' industry.

\section{Problem Question}

"Is it possible to implement a centralised distribution model in the automotive component industry for supply to independent retailers?"

\section{Objectives}

The main objective of this article was to explore the possibility of developing a model for the implementation of a centralised distribution in the automotive component industry for supply to independent retailers. Consideration had to be given to certain issues in that the distribution model (1) would need to be practical; and (2) would need to deliver added value to automotive component manufacturers. 
The secondary objectives of the research were:

1. to give an overview of distribution strategies;

2. to give an overview of the pharmaceutical distribution chain as this study explores the possibility of developing a centralised distribution model for the automotive component industry for supply to independent retailers, similar to the South African pharmaceutical industry one;

3. to give an overview of the existing automotive component manufacturers' distribution chain;

4. to explore the relevance of a distribution model for automotive component manufacturers;

5. to develop a model to formulate the implementation of a centralised distribution model for automotive component manufacturers for supply to independent retailers; and

6. suggest how this model could be implemented.

\section{Data Collection}

Primary research was conducted by way of semi-structured interviews, using an interview guide, with a senior staff member from a leading automotive component manufacturer in KwaZulu Natal and nine participants, at a senior management level, employed at five of their main customers (aftermarket retailers). Open-ended questions were found to be most suitable for this research study as Saunders, Lewis and Thornhill (2003:293) note that these are used widely in in-depth and semi-structured interviews.

\section{Participants}

Ten participants were included in this study, namely one participant in a leading automotive component manufacturer located in KwaZulu Natal and nine participants employed at five of their main customers (aftermarket retailers).

\section{Data Analysis}

Each interview was transcribed in a report format, after which it became possible to summarise, compare and consolidate the findings of each participant. The results are of a descriptive nature and are dealt within the analysis and interpretation of the findings.

\section{Validity and Reliability}

According to Saunders et al (2003:101), in terms of validity, the concern is whether the "findings are really about what they appear to be about". Cavana, Delahaye and Sekaran (2000:212) note that numerous types of validity tests are utilised to test the goodness of measures. Validity tests can be classified under four broad headings, namely face validity, content validity; criterion related validity and construct validity. In this research study, both face validity and content validity tests were used.

Reliability was another important aspect to consider in this study. Cavana et al (2000:210) observe that the reliability of a measure indicates the stability and consistency with which the instrument measures the concept that helps assess the 'goodness' of a measure.

In order to achieve this, extensive notes were taken during the interviews and copies of all transcribed interviews have been kept on file. 


\section{Limitations}

The study has the following limitations:

1. It was a preliminary study.

2. A limited number of participants were included in the study, namely one automotive component manufacturer and five of the automotive component manufacturer's main customers (aftermarket retailers).

3. The researcher was unable to obtain an accurate number of all independent retailers in South Africa, hence the number of independent retailers is not inclusive.

4. All of the proposals and aspects of the model are of an exploratory nature and are the focus of a further study that will be tested empirically.

\section{Way Forward}

From the preliminary study a centralised distribution model for automotive component manufacturers for supply to independent retailers has been developed. This model is of an exploratory nature. It is proposed that further research will be undertaken to test the model and to include all automotive component manufacturers to determine the need for, and the feasibility and validity of, this model.

\section{ANALYSIS AND INTERPRETATION OF THE FINDINGS}

The findings have been categorised in three sections, namely a description of the existing distribution chain of automotive component manufacturers in South Africa, a summary of the characteristics of the industry and the results of the interviews with the automotive component manufacturer's customers. These follow:

\section{The Existing Distribution Chain of the Automotive Component Manufacturers in South Africa}

As indicated in the South African Automotive Yearbook, 2008, Section 2.1, there are approximately 300 vehicle component manufacturers in South Africa. The National Association of Automotive Component and Allied Manufacturers (NAACAM) was launched 26 years ago to represent the interests of automotive component manufacturers. This body is both nationally and internationally recognised as the voice of the South African automotive component industry. NAACAM consists of some 190 national member companies.

The combined annual sales for 2008 of all members of NAACAM is estimated at R48 billion. The split of sales is made up as follows:

jales to vehicle assemblers for assembly $\quad 43 \%$

jales to the vehicle assemblers aftermarket $\quad 8 \%$

ndependent local aftermarket $\quad 11 \%$

Export sales $38 \%$

(Naacam 2009 Directory, 2008:21)

As per the figures obtained from the Retail motor Industry (RMI), the association has 501 members of which 385 are independent retailers.

From the interview with the participant from the automotive component manufacturer involved in this study, it was found that the majority of sales are through the major distribution groups. The automotive component manufacturer's split of distribution through the major distribution groups versus the independent retailer is estimated to be 75:25.

A characteristic of the aftermarket distribution channel is that the manufacturer / supplier is not in the business of product distribution. Its core business is manufacture, which leaves the distributor to 
handle the rest. South Africa is large and the distribution network broad, hence the need for a good relationship of trust to be developed between the supplier and the distributor.

There are various distribution channels in South Africa handling components supplied from component manufacturers. The various types of channels are listed in the following diagrams labeled figure 2(a), 2(b) and 2(c).

Figure 2(a): Components distribution channel - Midas / NAPA model

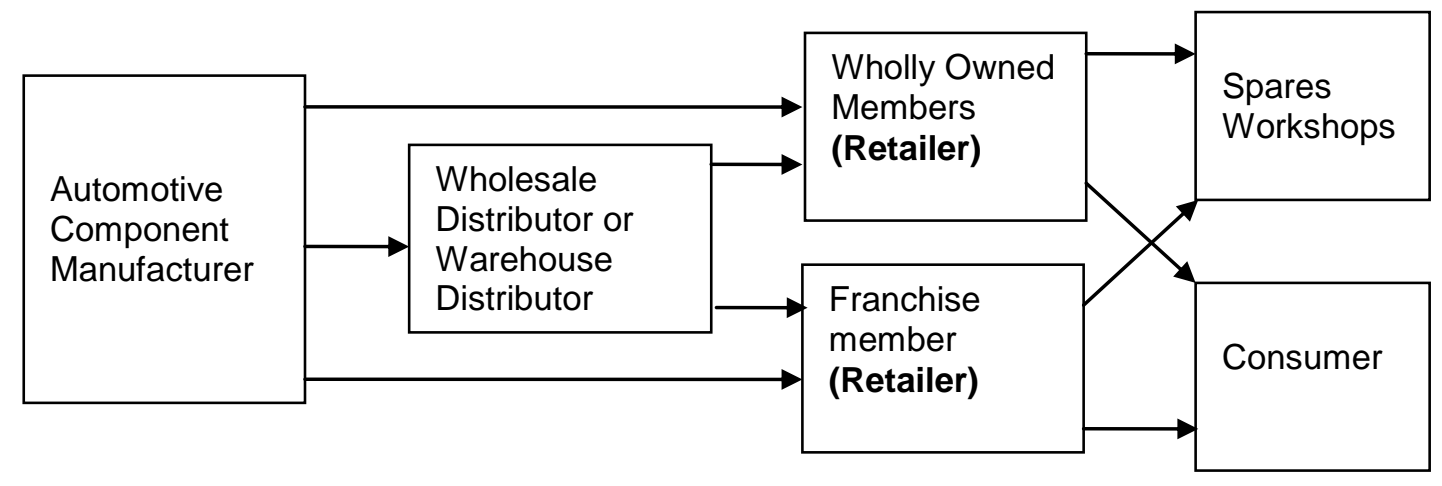

Source: Researcher's own construction

As can be seen from figure 2(a) the automotive component manufacturer sells directly to the wholly owned Midas member or to the NAPA franchisee who then sells on to the consumer or to spares workshops. Alternatively the wholly owned retailer or independent franchise member could obtain supply from the regional Parts Incorporated Africa (PIA) warehouse (wholly owned by Midas) or from the warehouse distributors (regional independently owned suppliers located in certain regions). Again the retailer will supply on to the consumer or to the spares workshops.

Figure 2(b): Component distribution channel - the Supergroup / Autozone model

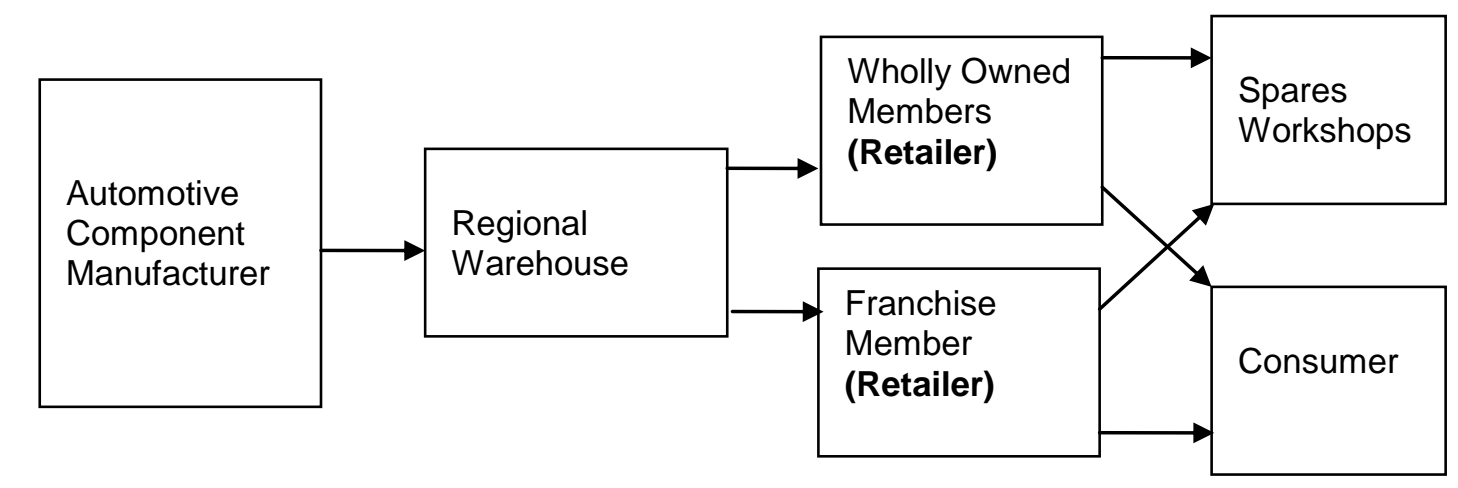

Source: Researcher's own construction

As can be seen from figure 2(b) the automotive component manufacturer sells directly to the Supergroup regional distribution warehouse who then supplies the wholly owned retailer or independent franchise member. These retailers supply on to the consumer or to the spares workshops. 
Figure 2(c): Component distribution channel - the Independent Retailer model

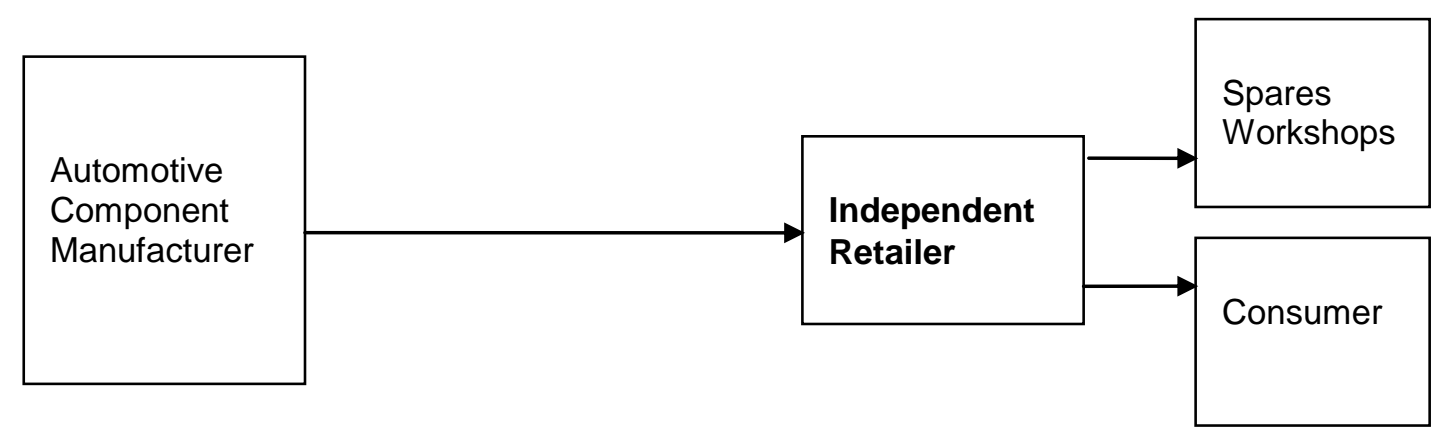

\section{Source: Researcher's own construction}

As can be seen from figure 2(c) the automotive component manufacturer sells directly to the independent retailer who then supplies on to the consumer or to the spares workshops. In certain cases the smaller independent retailer could source components through an intermediary or regional warehouse such as the PIA warehouse or independent regional warehouse distributor (part of the NAPA/Midas group).

Prices from the manufacturer / supplier are differentiated, based on whether the customer is a wholesale distributor, large retailer or spares outlet. This means that the prices are very dependent on the delivery volumes. The greater the bulk quantities (or complete pallet lots supplied), the lower the selling price charged by the manufacturer. It must be understood that the manufacturer pays for the freight or carriage costs. Therefore the freight cost in relation to the invoice value of the stock is significant on the smaller consignments. This is the reason for the creation of the bulk discount structure, to encourage larger shipments.

As a consequence, the price weighting of products favours the major wholesaler groups. The two main buying groups or super distributors in the country dominate the market:

1. Midas Limited/NAPA franchisees. The Midas Group consists of PIA, the national hub and spoke distribution business, NAPA, the marketing co-operative to the members of leading local brands, and franchises Midas, Motolek, ADCO and CBS that provide a network of some 320 retail outlets, workshops and fitment centres (Parts Incorporated Africa, 2009).

2. Autozone (Super Group). Autozone has over 170 stores of which 70 are member owned (franchises) (Autozone, 2009).

Midas, for example, offers added value in that (1) the group offers the consumer a greater choice of brands; (2) the group has a good communications channel up and down the chain - in the form of physical and electronic communications; and (3) they have brand awareness - the consumer knows the Midas brand (South African Automotive Yearbook, 2008: section 4).

Competing against these two super wholesalers are the independent retailers. These businesses either buy directly from the manufacturer or obtain supply via the Midas / PIA distribution warehouses.

\section{A Summary of the Characteristics of the Industry}

After interviewing all participants and analysing the interview responses the following issues were noted: 
- The aftermarket motor component industry is mature with the role players well established. Everyone knows everyone in the industry and new role players have difficulty entering.

- The industry follows conservative business practices.

- There is little volume growth in the industry: it has grown at an annual rate of no more than 3 $4 \%$ (this could change in view of the current economic downturn).

- The market is highly fragmented.

- The distribution chain to the market is long and expensive for the automotive component manufacturers.

- The market is dominated by the manufacturers / suppliers and the larger groups.

\section{A Summary of the Results of the Interviews with the Automotive Component Manufacturers' Customers}

After collating the results of the interview responses of the various customers the following issues emerged:

- Within the automotive retail aftermarket, quality is expected. After the issue of quality has been addressed (i.e. that quality spares are available), then the market is fairly price sensitive and this is dependent on the length of the components supply chain. The component retailers are proficient traders and are good at optimising revenue by sourcing from various intermediaries within the chain.

- Cheaper automotive components have been / are being imported; however the emergence of foreign imports is aimed at the lower end or the cheaper segment of the retail market rather than the more formal and advanced sector where the notion of "cheap and nasty" is a concern.

- There is an exceptionally high percentage of repeat orders by regular customers across the supply chain. For example, the same basket of product is being ordered on a regular basis e.g. weekly / monthly.

- The retailers add considerable value to the chain by offering a "basket of goods" to their customers. The customer wants a one stop shopping experience.

- There are varied levels of internet and technology capability within the chain. The larger distributors, and franchise members are generally more web-enabled than the independent distributors.

- Distributors / retailers see few e-commerce benefits in interactions between themselves and their customers. Most distributors / retailers had not really identified e-commerce opportunities on the buying side of their business i.e. between the supplier and themselves.

- E-commerce is impacting on the retail sector but entry into this arena is more difficult for the smaller independent retailer due to high cost.

- The main drivers of change in the industry regarding e-commerce come mainly from the buying groups, and then from the manufacturers. The retailers (except the larger groups) are not seen as a force in the e-commerce environment. 


\section{PROPOSED CENTRALISED DISTRIBUTION MODEL}

The primary aim of this research was to develop a model to formulate the implementation of a centralised distribution model for automotive component manufacturers for supply to independent retailers. In order to achieve this, a preliminary study was undertaken involving various participants. As indicated in the introduction, businesses must be competitive in order to sell their goods and services in the marketplace. Therefore, the proposed distribution model needs to add value to: (1) the independent retailers; and (2) the automotive component manufacturer. Value added could be achieved by eliminating manual work and / or redirecting resources, and therefore reducing costs.

A model has been developed and can be seen in figure 3 . It is suggested that between them automotive component manufacturers create a logistics company with various regional warehouses which would stock and distribute their products. The proposed logistics company is referred to as "Automotive Component Distributors". This logistics company would need to generate charges to cover their operational and distribution costs.

This model is described in detail in the following section. It is recommended that the implementation of the proposed distribution model process be undertaken in three phases. These three phases are discussed as follows:

\section{Figure 3: Proposed centralised distribution model}

\section{“AUTOMOTIVE COMPONENT DISTRIBUTORS”}

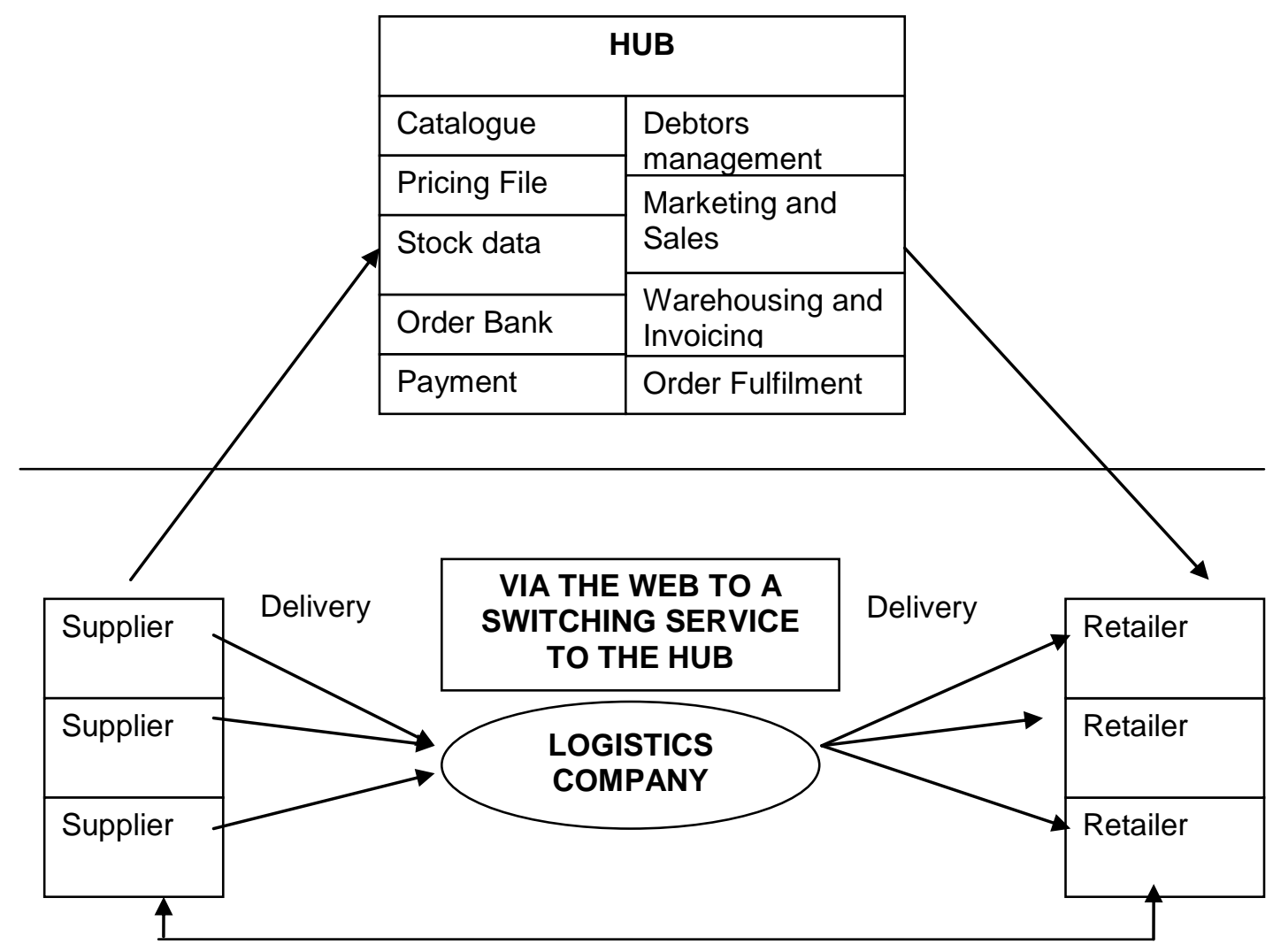

Source: Researcher's own construction 


\section{Phase One: Planning stage}

The first step would be to join forces with other automotive component manufacturers, who would want to be party to some form of market collaboration scheme in order to improve the distribution to independent retailers.

It would be necessary to contact the other automotive component manufacturers to ascertain whether these individuals would be willing to join in the creation of a hub similar to the one implemented by the pharmaceutical industry. During phase one a company could be launched.

The collaboration of many of the major automotive component manufacturers may be viewed by the other buying groups as "threatening" to them. However, as the distribution chain to the independent retailer is expensive for the automotive component manufacturer, the aim of the proposed centralised distribution model is to reduce distribution costs for the manufacturer. The intent of the proposed centralised distribution model is not to eliminate existing buying groups.

\section{Phase Two: The setting up of an e-commerce transacting facility}

Once phase one is complete, the second phase will involve the setting up of an e-commerce transaction facility. To arrive at the suitable applications software, specifications will need to be compiled. Individuals from various automotive component manufacturers will be co-opted onto a team to ensure that the specifications incorporate the correct attributes. Armed with these specifications the correct software package can be identified.

A project team will be needed to implement and test the facility. The e-commerce facility will then be appended to the automotive component manufacturer's web site address which will take the browser into the web site. Although access to the basic web site will be open to all, access to the transacting portion of the web site will be by password only.

Each current customer will be provided with password access. Customers with access will, include independent retailers as well as any other individuals whom the automotive component manufacturer accepts as a customer.

This site will include the following facilities:

1. stock enquiry data - availability, commitments etc.

2. cross reference checking components either by vehicle or part number

3. electronic ordering - the normal shopping basket approach to buying. The password access must show the customer the price level per part number that he will obtain (in line with current price lists per customer)

4. credit limit checking by the customer - to ascertain the balance of the credit limit available to buy against

5. credit limit review - to let the customer know if he has exceeded his credit limit

6. tracking of any consignment per order number: the progress of the stock movement

7. the cost of the consignment per order number

8. the invoice number per consignment plus the expected payment date

9. an electronic statement against which the customer will pay

10. electronic payment facilities to pay for the purchases

11. details of any promotions.

A suitable data / history system should be incorporated into the facility to gather appropriate history data on the customer - for example, sales trends per part number. This will assist in demand management and forecasting. 


\section{Phase Three: Translating the hub into a logistics operation}

Phase three will consist of translating the hub into a logistics operation. In line with the model developed and implemented by the South African pharmaceutical industry, it is suggested that a third party logistics provider may need to be brought into the process to handle warehousing and distribution. Manufacturers / suppliers will participate in pooled delivery, where the third party logistics provider will arrange consolidation for multiple component orders serving the same geographical market area and will distribute directly to the independent retailers. This could involve the use of regional warehouses operated by the third party logistics provider. As can be seen from figure 4, the suppliers will despatch the stock to these warehouses on a consignment basis. The logistics company will be responsible for storing, managing and distributing the stock (basket of various components) to the independent retailers.

Figure 4: Consolidation arrangement of "Automotive Component Distributors"

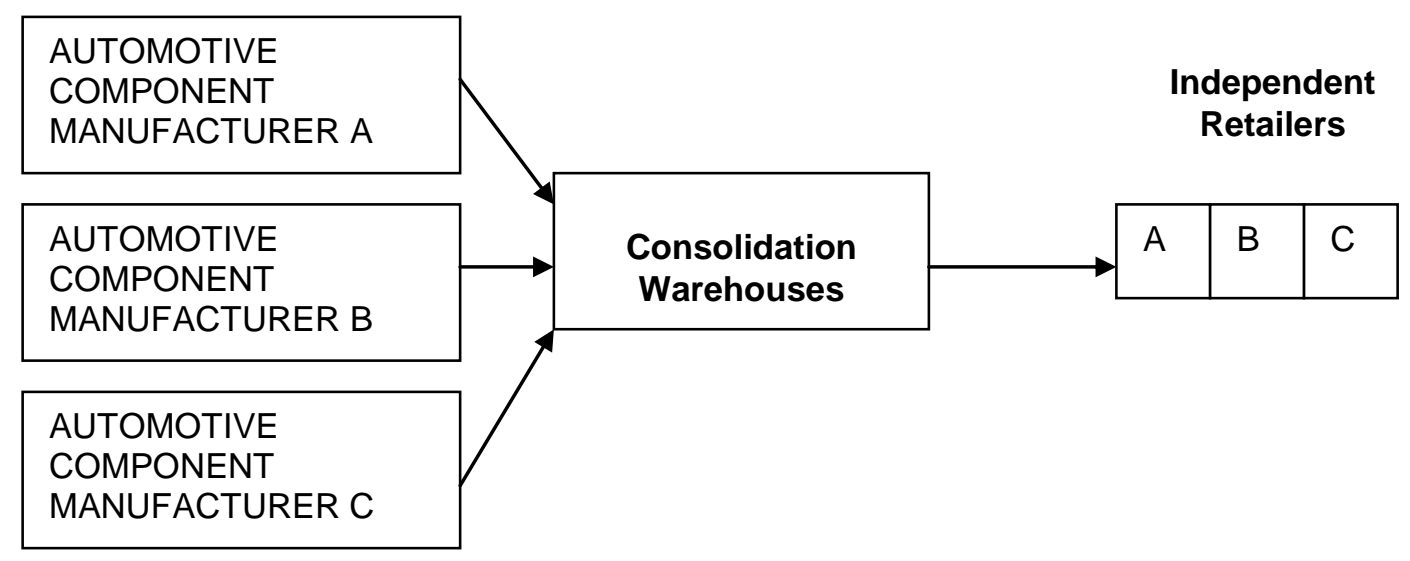

Source: Adapted from Bowersox et al (2002:383)

It is recommended that the characteristics of "Automotive Component Distributors" be as follows:-

- independent: Automotive Component Distributors could be created and operated as a separate legal entity. Ownership and governance responsibility could be shared by the founding / investing companies.

- channel focused: Automotive Component Distributors could support suppliers' current retail and distributor channel partners. The aim of the proposed centralised distribution model for supply to independent retailers is to improve operations and reduce distribution costs for the manufacturer.

- branding: Automotive Component Distributors' intention should not be to create a new "product" brand identity; rather, the individual participants should be able to further develop their own brands by leveraging Automotive Component Distributors' value-added services.

- open architecture: the technology for Automotive Component Distributors could allow for a variety of interfaces from buyers' and sellers' current systems, including Microsoft and Netscape browsers, EDI, SML and direct ERP connectivity.

- other exchanges: Automotive Component Distributors could be designed to support links to a variety of other exchanges.

- scalable: the idea would be to implement Automotive Component Distributors with some initial players and then scale up the membership. The solution should be able to grow and expand as the demands on it increase. 


\section{MANAGERIAL / ECONOMIC IMPLICATIONS}

It is envisaged that there could be both managerial and economic implications and benefits of such as solution as follows:

- Automotive Component Distributors could allow participants to better manage aftermarket sales, in the face of moves by others who seek to act as intermediaries in this value chain.

- Automotive Component Distributors could also offer distributors and retailers quick, efficient online access to the majority of the part types they need, combined with any ability to track shipments resulting in improved customer service.

- Catalogue ordering could:

- be searchable by part number and attributes;

o provide broadest possible coverage; and

$\circ$ improved accuracy and dependability.

- Internet-enabled improvement in operations could include:

$\circ$ on-line order tracking and advance shipping notice;

o better visibility of processes and performance for better decision-making;

o on-line analytical services driven by information from multiple buyers and sellers;

o ship directly from manufacturer / supplier to consumer, if and where the retail counterman requests it;

o more accurate handling of transactions where an order is placed by the customer to the supplier; and

$\circ$ automated financial tracking and reporting.

- Improved market information for manufacturers, in terms of customer buying patterns and trends, could result from this model.

\section{CONCLUSION}

The purpose of this article was to explore the possibility of developing a distribution model which could be implemented in the automotive component industry for supply to independent retailers by manufacturers. The scope of this article is limited to the sell side of the value chain and based on a preliminary study.

This article commences with an introduction, outlining the study and why the study was undertaken. This was followed with the theoretical background to the study which identified and listed the categories of business in the automotive industry. Porter's value chain is included to stress the point that distribution is a primary activity, the aim of which is to increase profit margins by creating value.

With regard to distribution strategies, both centralised versus decentralised systems were briefly dealt with. The centralised system was the focus of this article as currently the distribution chain from automotive component manufacturers to independent retailers is decentralised. Likewise, the pharmaceutical industry's distribution chain was previously decentralised and the industry has subsequently developed a unique distribution model. The aim of this study was to determine whether a similar model could be developed for automotive component manufacturers.

The methodology includes the purpose of the study, the problem question, objectives data collection, data analysis, validity and reliability, the limitations of the study and the way forward. 
The findings from the empirical study suggest that the aftermarket component industry is mature with the role players well established. The distribution chain to the independent retailer is expensive for the automotive component manufacturer. A proposed centralised distribution model for supply to independent retailers has been developed which would reduce distribution costs for the manufacturer in terms of (1) the lowest possible freight rate; (2) timely and controlled delivery; and (3) reduced congestion at the customer's receiving dock.

To answer the research question:

"Is it possible to implement a centralised distribution model in the automotive component industry for supply to independent retailers?"

The distribution model as suggested is a practical one and should deliver added value to automotive component manufacturers in that it could reduce distribution costs for the manufacturer and also improve customer service.

\section{REFERENCES}

About IHD (2008). Available [online] www.ihd.com/detailed.asp. Accessed 25 January 2009

Andel, T. (2008). Survival in the Drug Chain. Modern Materials Handling. Warehousing Management Edition. Boston January 2008, Vol. 63, Issue 1; p. 7, 1pgs.

Applegate, L.M. \& Collins, E.L. (2005). Covisint (A): The Evolution of a B2B Marketplace. Harvard Business School, June 29 2005. (9-805-110).

Autozone (2009). Available [online] www.supergroup.co.za/operating-retail-supply.html. Accessed 6 February 2009.

Barnes, J.R. \& Morris, M. (2008). Staying alive in the global automotive industry: what can developing economies learn from South Africa about linking into global automotive value chains. The European Journal of Development Research. Volume 20 No. 1. March 2008, 31-55

Benton, W.C. (2007). Purchasing and Supply Management. International Edition. Boston: McGrawHill.

Bowersox, D.J., Closs, D.J. \& Cooper, M.B. (2002). Supply Chain Logistics Management. International Edition. Boston: McGraw-Hill.

Bowersox, D.J., Closs, D.J. \& Cooper, M.B. (2007). Supply Chain Logistics Management. International Edition. Boston: McGraw-Hill.

Buzzavo, L. (2008). Business Strategies and Key Success Factors for Automotive Retailers: The Case of Dealer Groups in Italy. International Journal of Automotive Technology and Management. Volume 8, Number 1/2008. (p. 105-119)

Cavana, R.Y., Delahaye, B.R. \& Sekaran, U. (2000). Applied Business Research: Qualitative and Quantitative Methods. Australia: John Wiley \& Sons, Inc

Competition Tribunal Republic of South Africa (2000). Case Number 68/R/JUN00

Grant, D.B., Lambert, D.M., Stock, J.R. \& Ellram, L.M. (2006). Fundamentals of Logistics Management. European Edition. London: McGraw-Hill. 
Hill, C.W.L \& Jones, G.R. (2004). Strategic Management. An Integrated Approach. Sixth Edition. Boston: Houghton Mifflin Company.

Hugo, W.M.J, Badenhorst-Weiss, J.A. \& van Biljon E.H.B. (2004). Supply Chain Management. Logistics in Perspective. Pretoria: Van Schaik Publishers.

Jones, G.R \& George, J.M. (2003). Contemporary Management. International Edition. Boston: McGraw-Hill.

Jonsson, P. (2008). Logistics and Supply Chain Management. London: McGraw-Hill

Kotler, P (2000). Marketing Management. Eleventh Edition. New Jersey: Prentice-Hall

Laudon, K.C \& Laudon, J.P. (2004) Management Information Systems. Managing the Global Firm. Eighth Edition

Mangan, J., Lalwani, C. \& Butcher, T. (2008). Global Logistics and Supply Chain Management. Great Britain: John Wiley \& Sons Ltd.

Manufacturing (2009). Available [Online] www.covisint.com/industries/ automotive/index.shtml. Accessed_31 August 2009.

Naacam 2009 Directory. (2009). Naacam and the Automotive Component Industry. Balgair Publications

Parts Incorporated Africa (2009). Available [Online] www.midas.co.za. Accessed 9 February 2009.

Pearce, J.A. \& Robinson, R.B. (2007). Strategic Management. Formulation, Implementation and Control. Tenth Edition. Boston: McGraw-Hill Irwin.

Saunders, M., Lewis, P. \& Thornhill, A. (2003). Research Methods for Business Students. Third Edition. Harlow, England: Prentice Hall.

Simchi-Levi, D., Kaminsky, P. \& Simchi-Levi, E. (2008). Designing and Managing the Supply Chain: Concepts, Strategies and Case Studies. Third Edition. Boston: McGraw-Hill.

South African Automotive Yearbook (2008). Definitive Reference, Statistics \& Data on the South African Motor Industry. Eleventh Edition. NAACAM, Section 2: Component Manufacturing. Section 2.1. Balgair Publications.

South African Automotive Yearbook (2008). Definitive Reference, Statistics \& Data on the South African Motor Industry. Eleventh Edition. NAACAM, Section 4: Automotive Retail and Aftermarket. Midas MD Automobil's Person of the Year. Balgair Publications

Stevenson, W.J. (2005) Operations Management. Eighth Edition. International Edition. Boston: McGraw-Hill.

Stevenson, W.J. (2009). Operations Management. Tenth Edition. Boston: McGraw-Hill.

Thompson, A.A., Gamble, J.E. \& Strickland, A.J. (2006). Strategy. Winning in the Marketplace. Core Concepts, Analytical Tools, Cases. Second Edition. Boston: McGraw-Hill Irwin.

UTi Acquires Leading Pharmaceutical Distributor IHD (2004). [Online] http://www.go2uti.com/ news/ihd news.html. Accessed 29 January 2009. 